\title{
Pregnancy in patients with Wegener's granulomatosis: report of five cases in three women
}

Christophe Auzary, Du le Thi Huong, Bertrand Wechsler, Danièle Vauthier-Brouzes, Jean-Charles Piette

\begin{abstract}
Five cases of pregnancy occurring in three women with previously diagnosed Wegener's granulomatosis are described. The disease was diffuse in one case and localised in the other. Initial treatment consisted of a combination of corticosteroids and intravenous cyclophosphamide in two women, and methotrexate in one. Four pregnancies ended in live births despite pre-eclampsia in two cases. One therapeutic abortion was induced because of encephalocele. Comparable reported cases were reviewed to examine the implications of immunosuppressive treatment on the fetus. A relapse occurred during pregnancy in $40 \%$ of the cases, but in $25 \%$ if only pregnancies beginning during inactive disease were taken into account. No other indicator for maternal and fetal outcome was obvious. Pregnancy should be planned after complete disappearance of disease activity. In the case of a relapse a combination of immunosuppressive drugs and corticosteroids should be chosen rather than corticosteroids alone because the outcome of pregnancy is poor in cases of undertreatment. Prematurity remains common.
\end{abstract}

(Ann Rheum Dis 2000;59:800-804)

Department of Internal Medicine, Hôpital de Bicêtre, 78 avenue du general leclerc, 94270

Le Kremlin-Bicetre, France

C Auzary

Department of Internal Medicine, Groupe Hospitalier Pitié-Salpêtrière, 83 boulevard de

l'hôpital, 75651 Paris Cedex 13, France

D le Thi Huong

B Wechsler

Department of Gynecology-Obstetrics, Groupe Hospitalier Pitié-Salpêtrière

D Vauthier-Brouzes J-C Piette

Correspondence to: Dr Auzary

Accepted for publication 9 March 2000
Wegener's granulomatosis (WG) is an uncommon systemic vasculitis of unclear pathophysiology. It usually affects the upper respiratory tract, the lungs, and the kidneys. Before the introduction of effective treatment the one year mortality rate was $82 \%$. Currently, a combination of corticosteroids and cyclophosphamide induces remission in most patients, ${ }^{1}$ but relapses are common and may occur several years after remission. ${ }^{2}$ The incidence of WG peaks in the fourth and fifth decades with a slight male predominance. Hence, reports of pregnancy in patients with WG are few. Improvement of the prognosis of WG may increase the number of pregnancies monitored. The influence of pregnancy on WG and vice versa, the management of these patients taking into account possible life threatening complications of WG, and the potential teratogenic effect of immunosuppressive drugs should be precisely determined. We report five pregnancies in three patients with previously diagnosed WG and review previous similar reports in French and English publications.

\section{Case reports}

CASE 1

A 30 year old woman with type I diabetes mellitus since the age of 20 was pregnant in 1990 and 1992, with full term deliveries by caesarean section for dystocia. She presented in October 1993 with a three month history of otitis media, sinusitis, haemoptysis, and arthralgias. A chest radiograph displayed mild bilateral infiltrates. Alveolar haemorrhage was confirmed by bronchoalveolar lavage study. There was no renal disease. Histological examination of a nasal biopsy specimen specimen showed giant cell granuloma and necrotising leucocytoclastic vasculitis. Cytoplasmic antineutrophil cytoplasmic antibodies (c-ANCA) were positive with antiproteinase 3 specificity. Monthly $1 \mathrm{~g}$ intravenous cyclophosphamide pulses together with prednisone $1 \mathrm{mg} / \mathrm{kg}$ daily were started. Remission was achieved within three months, with negative c-ANCA. Cyclophosphamide was stopped in February 1995 (cumulative dose $18 \mathrm{~g}$ ) and prednisone was progressively tapered to $5 \mathrm{mg}$ daily in August 1995. Maintenance treatment then comprised hydrocortisone $20 \mathrm{mg}$ daily because of adrenal insufficiency, associated with co-trimoxazole (320 mg trimethoprim and $1600 \mathrm{mg}$ daily sulfamethoxazole) until August 1995. Co-trimoxazole was then withdrawn because she wanted to become pregnant. In January 1996 a therapeutic abortion was carried out at 12 weeks' gestation because of a massive fetal encephalocele. Serum folate level (without any supply), acetylcholinesterase electrophoresis, and fetal karyotype were normal.

A fourth pregnancy began in March 1996 while she was receiving hydrocortisone $20 \mathrm{mg}$ daily. Obstetric echography was normal. The pregnancy was uneventful until October 1996. At 37 weeks, hypertension $(150 / 90 \mathrm{~mm} \mathrm{Hg})$ with proteinuria ++ , raised uric acid (525 $\mu \mathrm{mol} / \mathrm{l})$ and thrombocytopenia $\left(88 \times 10^{9} / 1\right)$ appeared without haemostasis, and liver enzymes were abnormal. No flare up of WG was obvious. ANCA testing remained negative. Caesarean section delivered a healthy $4170 \mathrm{~g}$ girl. APGAR scores were 8 and 10 at one and five minutes. No relapse of WG was noted while receiving hydrocortisone $20 \mathrm{mg}$ daily.

A fifth pregnancy began in June 1999. Her WG was in remission with negative ANCA and she was receiving no treatment. The course of the pregnancy was unenventful except for the occurrence of a retroplacental haematoma in December. Subsequent ultrasound examinations showed its resorption. Delivery was 
induced by caesarean section at 35 weeks because of macrosomia. A $4620 \mathrm{~kg}$ healthy boy was born with APGAR scores of 10 at one and five minutes. At the present time her WG remains in remission without treatment, with negative ANCA. All the children are well.

CASE 2

A 27 year old woman had had a previous normal pregnancy three years previously when she complained, in April 1993, of a one month history of nasal obstruction, otalgias, arthralgias, and haemoptysis. Chest radiographs showed multiple bilateral nodules, one of them excavated. A histological study of a lung surgical biopsy specimen showed necrotic giant cell granuloma. Cough and rhinitis rapidly improved during treatment with prednisone 0.5 $\mathrm{mg} / \mathrm{kg}$ daily. One month later, a relapse occurred. Her serum creatinine level rose from 280 to $509 \mu \mathrm{mol} / 1$ in one week. A histological study of a renal biopsy specimen showed diffuse crescentic glomerulonephritis with severe tubulointerstitial inflammation. c-ANCA were positive with antiproteinase 3 specificity. Three pulses of methylprednisolone $1 \mathrm{~g}$ daily were started, followed by prednisone $1 \mathrm{mg} / \mathrm{kg}$ daily and monthly $750 \mathrm{mg}$ intravenous cyclophosphamide pulses. Remission was achieved within four months, with negative c-ANCA and a dramatic drop in the serum creatinine level to $120 \mu \mathrm{mol} / 1$. Cyclophosphamide was stopped in October 1995 (cumulative dose $13.5 \mathrm{~g}$ ), and prednisone was progressively tapered to $5 \mathrm{mg}$ daily together with cotrimoxazole (trimethoprim $160 \mathrm{mg}$ and sulfamethoxazole $800 \mathrm{mg}$ daily).

She became pregnant in March 1997. Her prednisone dose was systematically increased to $10 \mathrm{mg}$ daily and co-trimoxazole was stopped. In November 1997 hypertension $(145 / 90 \mathrm{~mm} \mathrm{Hg})$ appeared with oedema in the legs, proteinuria ( $0.7 \mathrm{~g}$ daily), raised uric acid (327 $\mu \mathrm{mol} / \mathrm{l}$ ), but a stable serum creatinine level, normal platelet count, and normal liver enzymes. No flare up of WG occurred. ANCA testing remained negative. At 35 weeks after an induced vaginal delivery she gave birth to a $3120 \mathrm{~g}$ healthy boy. The APGAR score was 10 at one and five minutes. After three years' follow up, mother and child are well. No relapse of WG was seen while receiving co-trimoxazole (trimethoprim $160 \mathrm{mg}$ and sulfamethoxazole $800 \mathrm{mg} /$ daily) and prednisone $5 \mathrm{mg}$ daily.

CASE 3

A 20 year old woman complained in 1984 of chronic rhinitis and otitis media complicated with mild hearing loss. Two years later, acute dysphonia and dyspnoea led to the discovery of subglottic stenosis. A histological examination of a tracheal biopsy specimen showed necrotic giant cell granuloma. ANCA testing was negative. Treatment comprised laser vaporisation that was initially successful, but several relapses occurred needing successive laser treatments. In 1990 a solitary excavated nodule was discovered by thoracic $x$ ray examination. Rhinitis and laryngitis were present without sinusitis or renal disease. Subglottic stenosis was stable. ANCA testing was negative. Co-trimoxazole (trimethoprim $160 \mathrm{mg}$ and sulfamethoxazole $800 \mathrm{mg}$ twice daily) was started with success, but a relapse occurred four years later as the patient withdrew herself from this treatment. Bronchoscopic dilatation was associated with prednisone $1 \mathrm{mg} / \mathrm{kg}$ daily and methotrexate $7.5 \mathrm{mg}$ weekly. In 1997 she wanted to become pregnant again and methotrexate was stopped. When pregnancy was diagnosed, prednisone $20 \mathrm{mg}$ daily was started. The course of her pregnancy was uneventful apart from diabetes, which was treated. At 39 weeks a caesarean section was carried out because of dystocia; she delivered a healthy $3750 \mathrm{~g}$ boy. The APGAR score was 10 at one and five minutes. After one year's follow up, mother and child are well. No relapse of WG was seen despite a progressively decreased dose of prednisone.

\section{Discussion}

We report five cases of pregnancy in three women with biopsy proved WG. A longlasting remission before planning pregnancy was advised in all cases to avoid the teratogenic effect of drugs and relapse of WG. Four pregnancies ended in delivery of healthy eutrophic babies. No relapse of WG occurred.

Reports of pregnancy in WG are rare: 21 pregnancies in 17 patients with WG have been described in French and English language publications since $1970 .{ }^{3-18} \mathrm{WG}$ was diagnosed during pregnancy in six cases that ended in three premature births, ${ }^{31117}$ two therapeutic abortions ${ }^{513}$ and one maternal death. ${ }^{4}$ Six cases of WG onset or relapse occurred in the two to eight weeks' postpartum period..$^{7012131819}$ Apart from the present report, 15 pregnancies were reported in 11 patients with known WG (the case of Fields et $a l^{6}$ should also be included, though WG was diagnosed after pregnancy, because pauci-immune glomerulonephritis was treated with cyclophosphamide and corticosteroids) (tables 1 and 2). Mean age at pregnancy was 24.6 years (range 20-30). Five patients had become pregnant before disease onset. All patients had been treated with corticosteroids, together with azathioprine in five patients, and cyclophosphamide in eight. Cyclophosphamide was given orally in four cases with various lengths of treatment: $6,{ }^{68}$ $12,{ }^{9}$ or 18 months. ${ }^{16}$ It was given intravenously in four cases with varied cumulative doses: 1 $\mathrm{g},{ }^{715} 3 \mathrm{~g},{ }^{7}$ and $23 \mathrm{~g} .^{18}$ Of note, two of our patients became pregnant after at least 16 cyclophosphamide pulses.

Oral contraception is usually prescribed during cyclophosphamide treatment because of its teratogenic effect and to preserve ovarian function. ${ }^{8}{ }^{16}$ Fecundity after intravenous cyclophosphamide treatment has been well studied in systemic lupus. The incidence of ovarian failure varied between $11 \%$ and $59 \% .^{20}$ The main risk factors for ovarian failure were higher age at cyclophosphamide onset and cumulative dose. $^{20}$ No similar data about cyclophosphamide induced sterility are available for systemic 
Table 1 Pregnancies in patients with a known Wegener's granulomatosis (WG) or WG before pregnancy active at pregnancy onset

\begin{tabular}{|c|c|c|c|c|c|c|c|}
\hline $\begin{array}{l}\text { Author, } \\
\text { reference }\end{array}$ & $\begin{array}{l}\text { Age at } W G \\
\text { onset (years) }\end{array}$ & $\begin{array}{l}\text { Organs initially } \\
\text { affected }^{\star}\end{array}$ & $\begin{array}{l}\text { Initial } \\
\text { treatment }\end{array}$ & $\begin{array}{l}\text { Age at pregnancy } \\
\text { (years) }\end{array}$ & $\begin{array}{l}\text { Organs affected at } \\
\text { pregnancy onset }\end{array}$ & Complication/ treatment & Pregnancy outcome \\
\hline $\mathrm{M}^{\prime} \mathrm{Rad}^{12}$ & 24 & $\mathrm{E}, \mathrm{L}, \mathrm{S}, \mathrm{A}$ & CS & 25 & E, S L, K & $\begin{array}{l}\text { Relapse }(\mathrm{L}, \mathrm{S}) \\
\text { oCY }\end{array}$ & $\begin{array}{l}\text { Therapeutic abortion } \\
\text { Maternal death }\end{array}$ \\
\hline Pauzner $^{8}$ & 30 & E, L, K, S & $\begin{array}{l}\text { oCY, CS } \\
\text { AZA TS }\end{array}$ & $\mathrm{P} 2 \ddagger: 32$ & & $\begin{array}{l}\text { Subglottic stenosis } \\
\text { CS }\end{array}$ & Therapeutic abortion \\
\hline $\operatorname{Lima}^{7}$ & 24 & $\mathrm{E}, \mathrm{L}, \mathrm{S}, \mathrm{A}$ & pCY CS & 24 & S, A & $\begin{array}{l}\text { Relapse } \mathrm{T} 1 \ddagger(\mathrm{L}, \mathrm{S}, \mathrm{A}) \\
\text { CS }\end{array}$ & Spontaneous abortion \\
\hline Kumar $^{16}$ & 22 & $\mathrm{E}, \mathrm{K}$ & oCY, CS & 25 & $\mathrm{E}, \mathrm{A}$ & $\begin{array}{l}\text { Relapse T1 (E, A) } \\
\text { CS } \\
\text { Postpartum flare (L) }\end{array}$ & Spontaneous abortion \\
\hline
\end{tabular}

${ }^{\star} \mathrm{A}=$ arthralgia or arthritis; $\mathrm{E}=$ upper respiratory tract (ear, nose, throat) and eyes; $\mathrm{K}=$ kidney; $\mathrm{L}=$ lung and lower respiratory tract; $\mathrm{S}=$ skin. †AZA = azathioprine $\mathrm{CS}=$ corticosteroids $\mathrm{CY}=$ cyclophosphamide oCY $=$ oral $\mathrm{CY} ; \mathrm{pCY}=$ intravenous pulses of $\mathrm{CY}$; $\mathrm{TS}=$ trimethoprim-sulfamethoxazole . $\ddagger \mathrm{P} 2$ = second pregnancy; $\mathrm{T} 1$ = first trimester.

vasculitides, probably because these diseases generally affect older patients.

The influence of pregnancy on the course of WG is not precisely known. No flare up of WG occurred during or after pregnancy in our patients. In the literature, eight of 15 pregnancies with known WG were complicated by a relapse. Four relapses occurred while pregnancy had begun during active disease $\mathrm{P}^{71216}$ and four while WG was in remission. ${ }^{6} 81415$ WG activity at pregnancy onset seemed to be the main indicator of poor maternal and fetal prognosis as four of 15 pregnancies beginning during active WG ended in two spontaneous fetal deaths, one therapeutic abortion, and one maternal death despite therapeutic abortion. ${ }^{781216}$ Clinical activity correlated with positive ANCA at pregnancy onset in two cases. $^{716}$

Four relapses occurred despite remitted WG at pregnancy onset. ${ }^{681415}$ In two cases, ANCA remained positive despite clinical remission. ${ }^{8} 15$ ANCA monitoring was useful for individual cases: persistently reduced ANCA titres associated with clinical remission suggest inactive disease and help to authorise pregnancy. Nevertheless, apart from in the context of pregnancy, ANCA titres do not have an absolute predictive value for WG activity. Relapse rate was $25 \%$ among 16 pregnancies occurring in inactive WG. Of note, the postpartum period was uneventful in all our patients.

The length of time elapsing between the end of WG treatment and pregnancy onset, even if longer than two years, was not sufficient to avoid the risk of relapse. ${ }^{14}{ }^{16}$ However, pregnancy can be planned after a sufficiently longlasting remission. Of 15 pregnancies beginning in inactive WG, 14 ended in live births (one unrelated WG therapeutic abortion) (our patients and those reported in the following references)..$^{6-10141518}$

A long prior course of immunosuppressive treatment before pregnancy, and maintenance treatment at the onset of pregnancy, do not

Table 2 Pregnancies in patients with a known Wegener's granulomatosis (WG) or WG before pregnancy in remission at pregnancy onset

\begin{tabular}{|c|c|c|c|c|c|c|}
\hline Author, reference & $\begin{array}{l}\text { Age at } W G \\
\text { onset (years) }\end{array}$ & $\begin{array}{l}\text { Organs initially } \\
\text { affected }^{\star}\end{array}$ & Initial treatment $\uparrow$ & $\begin{array}{l}\text { Age at pregnancy } \\
\text { (years) }\end{array}$ & Complication/ treatment & $\begin{array}{l}\text { Pregnancy outcome Gestational age } \\
\text { (weeks)/ weight }(\mathrm{kg})\end{array}$ \\
\hline Cooper $^{10}$ & 25 & E, L & $\begin{array}{l}\text { AZA, CS, } \\
\text { Radiotherapy }\end{array}$ & ND & $\begin{array}{l}\text { Respiratory infection treated with } \\
\text { penicilline+ hydrocortisone }\end{array}$ & $\begin{array}{l}\text { Membranes rupture induced VD } \\
35 / 2.63\end{array}$ \\
\hline Harrison $^{14}$ & 16 & E, L & $\mathrm{AZA}, \mathrm{CS}$ & $\begin{array}{l}\text { P1キ: ND } \\
\text { P2: ND }\end{array}$ & & $\begin{array}{l}\text { Normal } \\
\text { Normal }\end{array}$ \\
\hline & & & & P3: ND & Relapse (L) & Normal \\
\hline Biesenbach $^{9}$ & 20 & $\mathrm{E}, \mathrm{L}, \mathrm{K}$ & $\begin{array}{l}\text { oCY, CS } \\
\text { Renal transplant } \\
\text { CS, CsA }\end{array}$ & 22 & T3ł: Pre-eclampsia & $\begin{array}{l}\text { Caesarean section } \\
\text { Twin } \\
33 / 1.350-1.18\end{array}$ \\
\hline Fields $^{6}$ & 18 & E, L, K, S, A & CY, CS & 23 & $\begin{array}{l}\text { T2: Relapse } \\
(\mathrm{E}, \mathrm{L}, \mathrm{S}, \mathrm{K}) \\
\mathrm{oCY}+\mathrm{CS}+\text { haemodialysis }\end{array}$ & $\begin{array}{l}\text { Caesarean section } \\
33 / 2.04\end{array}$ \\
\hline Pauzner $^{8}$ & 30 & $\mathrm{E}, \mathrm{L}, \mathrm{K}, \mathrm{S}$ & $\begin{array}{l}\text { OCY, CS } \\
\text { AZA TS }\end{array}$ & P1: 31 & $\begin{array}{l}\text { T2: Relapse } \\
\text { OS + laser }\end{array}$ & VD $38 / 2.77$ \\
\hline $\operatorname{Lima}^{7}$ & 29 & E, A & $\begin{array}{l}\text { pCY } \\
\text { AZA, CS }\end{array}$ & $\begin{array}{l}\text { P1: } 32 \\
\text { P2: } 33\end{array}$ & & $\begin{array}{l}\text { VD } 40 / 3.17 \\
\text { VD } 39 / 3.74\end{array}$ \\
\hline Parnham $^{15}$ & 21 & $\mathrm{~L}, \mathrm{~K}, \mathrm{~S}, \mathrm{~A}$ & $\begin{array}{l}\text { PC, PE, CS, } \\
\text { CS TS }\end{array}$ & 24 & $\begin{array}{l}\text { T2: Relapse } \\
(\mathrm{E}, \mathrm{L}, \mathrm{K}) \\
\text { oCY + CS } \\
\text { AZA + CS } \\
\text { Oligohydramnios }\end{array}$ & $\begin{array}{l}\text { Induced VD } \\
37 / 2.87\end{array}$ \\
\hline Koldingsnes $^{18}$ & 23 & E, K & $\begin{array}{l}\mathrm{CS} \text { pCY } \\
\mathrm{AZA}, \mathrm{CS}\end{array}$ & 28 & Postpartum relapse & $\begin{array}{l}\text { Normal } \\
\mathrm{ND} / 3.56\end{array}$ \\
\hline $\begin{array}{l}\text { Present report } \\
\text { No } 1\end{array}$ & 30 & E, L, A & $\begin{array}{l}\text { pCY, CS } \\
\text { Hydrocortisone, TS }\end{array}$ & $\begin{array}{l}\text { P1: } 32 \\
\text { P2: } 33 \\
\text { P3: } 35\end{array}$ & $\begin{array}{l}\text { Pre-eclampsia } \\
\text { Retroplacental haematoma } \\
\text { Macrosomia }\end{array}$ & $\begin{array}{l}\text { Therapeutic abortion for encephalocele } \\
\text { Caesarean section } 37 / 4.17 \\
\text { Caesarean section } \\
35 / 4.62\end{array}$ \\
\hline $\begin{array}{l}\text { Present report } \\
\text { No } 2\end{array}$ & 27 & $\mathrm{E}, \mathrm{L}, \mathrm{K}, \mathrm{A}$ & $\begin{array}{l}\text { pCY, CS } \\
\text { pCY, CS, TS }\end{array}$ & 31 & Pre-eclampsia & $\begin{array}{l}\text { Induced VD } \\
35 / 3.12\end{array}$ \\
\hline $\begin{array}{l}\text { Present report } \\
\text { No } 3\end{array}$ & 20 & E,L & $\begin{array}{l}\text { Laser } \\
\text { TS } \\
\text { MTX, CS }\end{array}$ & 34 & Dystocia & $\begin{array}{l}\text { Caesarean section } \\
39 / 3.75\end{array}$ \\
\hline
\end{tabular}

${ }^{\star} \mathrm{A}=$ arthralgia or arthritis; $\mathrm{E}=$ upper respiratory tract (ear, nose, throat) and eyes; $\mathrm{K}=$ kidney; $\mathrm{L}=$ lung and lower respiratory tract; $\mathrm{S}=$ skin.

+AZA = azathioprine; CS = corticosteroids; CsA = cyclosporin; $\mathrm{CY}=$ cyclophosphamide; oCY = oral CY; $\mathrm{pCY}=$ intravenous pulses of $\mathrm{CY}$; $\mathrm{MTX}=$ methotrexate; $\mathrm{PE}=$ plasma exchanges; $\mathrm{TS}=$ trimethoprim-sulfamethoxazole.

$\ddagger \mathrm{P} 1, \mathrm{P} 2, \mathrm{P} 3$ = first, second, third pregnancy; T1, T2, T3 = first, second, third trimester.

IVD = vaginal delivery; $\mathrm{ND}=$ no data. 
seem able to prevent relapse. ${ }^{6816}$ Among seven well documented relapses during pregnancy, WG treatment at pregnancy onset comprised prednisone, ${ }^{12}$ cyclophosphamide plus prednisone, ${ }^{7}$ co-trimoxazole in two cases, ${ }^{8}{ }^{15}$ while three patients had no treatment. ${ }^{6816}$ Among seven well documented pregnancies with no relapse (Harrison's letter provided no information about maintenance treatment ${ }^{14}$ ), WG treatment at pregnancy onset varied between no treatment in three cases (case No 3 and the report by $\mathrm{Lima}^{7}$, hydrocortisone (case No 1), co-trimoxazole and prednisone (case No 2), azathioprine and prednisone,${ }^{10}$ cyclosporin and prednisone in one twin pregnancy. ${ }^{9}$

The risk of relapse during pregnancy also does not correlate with the initial severity of WG. Occurrence of a relapse seems to be a priori unpredictable. This suggests the true influence of pregnancy on the course of WG. ${ }^{8}$

Implications of WG treatment according to pregnancy state and disease severity have been discussed by several authors. ${ }^{11} 1617$

Cyclophosphamide is contraindicated during pregnancy, but data on its real fetal toxicity are limited. ${ }^{3611} 1517$ Induced delivery was also indicated in order to shorten contact of the fetus with cyclophosphamide. ${ }^{11}$ Patients treated with a combination of immunosuppressors and corticosteroids had a more favourable pregnancy outcome ${ }^{6915}$ than those treated with corticosteroids alone. ${ }^{781216}$

Considerable experience has proved that azathioprine is safe during pregnancy. However, it is less effective than cyclophosphamide in WG.

Methotrexate is strongly contraindicated during pregnancy because of its early teratogenicity, referred to as the "aminopterin syndrome", ${ }^{21}$ and late fetal bone marrow toxicity. ${ }^{11}$ The critical period for teratogenicity is suspected to be between six and eight weeks after conception. Fetal exposure from 10 to 32 weeks after conception has not resulted in obvious malformations. ${ }^{22}$

Because of its folic acid antagonism, the manufacturers of co-trimoxazole advised against its use during pregnancy. Hence, this drug has been stopped in two of our cases. In the case of pregnancy with encephalocele, co-trimoxazole cannot be incriminated as it was stopped several months before conception. A large case-control study concluded that co-trimoxazole does not have a teratogenic effect. ${ }^{23}$ As a clear preventive effect of cotrimoxazole on WG relapse has been shown, ${ }^{24}$ its continuation during pregnancy should be discussed.

High dose immunoglobulins have been proposed in second line treatment in WG. ${ }^{25}$ They have never been evaluated in WG pregnancy, ${ }^{16}$ but in other conditions, such as antiphospholipid syndrome, ${ }^{26}$ they appeared to be safe.

Two patients developed pre-eclampsia in the third trimester. Diabetes, renal WG sequelae, or corticosteroids were present as risk factors. In the literature, pre-eclampsia was seen in one of eight patients with previous WG renal disease ${ }^{9}$ and in another patient with WG diagnosed during pregnancy. ${ }^{11}$ All four patients with pre-eclampsia were treated with corticosteroids. Pre-eclampsia should be distinguished from a flare up of WG by clinical and laboratory criteria, such as absence of hypertension (which is rare in a WG flare), presence of extra-renal manifestations, especially upper airways and lung disease, and ANCA titres.

Prematurity is common in WG pregnancies. Mean duration of gestation was 36 weeks (range 33-40). ${ }^{6-10} 15$ Corticosteroids use also seemed to be a risk factor for preterm delivery and pre-eclampsia in pregnant women with antiphospholipid syndrome. ${ }^{27}$

In conclusion, in patients with known WG, pregnancy may be authorised if the disease remains clinically inactive with longlasting remission while no treatment or co-trimoxazole treatment is given. Long term cyclophosphamide treatment does not systematically imply sterility. A flare up of WG may occur during pregnancy in more than one quarter of cases, but no predictive factor seems to be significant. Pre-eclampsia and prematurity associated with corticosteroids or prior renal disease are the most serious complications. Hence, these pregnancies should be considered as high risk and need careful monitoring by both obstetrician and doctor, similar to the monitoring required in other systemic diseases such as systemic lupus erythematosus.

1 Hoffman GS, Kerr GS, Leavitt RY, Hallahan CW, Lebowics RS, Travis WD, et al. Wegener's granulomatosis: an analysis of 158 patients. Ann Intern Med 1992;116:488-98.

2 Piercey S, Montanaro A. Recurrent Wegener's granulomatosis: a case report and review. Ann Allergy Asthma Immunol 1996;76:317-20.

3 Talbot SF, Main DM, Levinson AI. Wegener's granulomatosis: first report of a case with onset during pregnancy. Arthritis Rheum 1984;27:109-12.

4 Milford CA, Bellini M. Wegener's granulomatosis arising in pregnancy. J Laryngol Otol 1986;100:475-6.

5 Palit J, Clague B. Wegener's granulomatosis presenting during the first trimester of pregnancy. Br J Rheumatol 1990; 29:389-90.

6 Fields CL, Ossorio MA, Roy TM, Bunke CM. Wegener's granulomatosis complicated by pregnancy. J Reprod Med 1991;36:463-6.

7 Lima F, Buchanan N, Froes L, Kerslake S, Khamashta MA, Hughes GRV. Pregnancy in granulomatous vasculitis. Ann Hughes GRV. Pregnancy in
Rheum Dis 1995;54:604-6.

8 Pauzner R, Mayan H, Hershko E, Alcalay M, Farfel Z. Exacerbation of Wegener's granulomatosis during pregnancy: report of a case with tracheal stenosis and iterature review. J Rheumatol 1994;21:1153-6.

9 Biesenbach G, Stöger H, Zazgornik J. Successful pregnancy of twins in a renal transplant patient with Wegener's granulomatosis. Nephrol Dial Transplant 1191;6:139-40.

10 Cooper K, Stafford J, Warwick MT. Wegener's granulomatosis complicating pregnancy. J Obstet Gynaecol 1970;77: $1028-30$.

11 Luisiri P, Lance NJ, Curran JJ. Wegener's granulomatosis in pregnancy. Arthritis Rheum 1997;40:1354-60.

12 M'Rad S, Moalla M, Ben Milled K, Falfoul A, Grossin M, Ben Jilani S, et al. Granulomatose de Wegener et grossesse: une observation. Rev Med Interne 1989;10:69-72.

13 Habib A, MacKay K, Abrons HL. Wegener's granulomatosis complicating pregnancy. Clin Nephrol 1996;5:332-6.

sis complicating pregnancy. Clin Nephrol 1996;5:332-6.
4 Harrison DFN. Ear, nose and throat symptoms in subacute Harrison DFN. Ear, nose and throat symptoms in subacut
Wegener's granulomatosis [letter]. BMJ 1989;299:791.

15 Parnham AP, Thatcher GN. Pregnancy and active Wegener's granulomatosis. Aust NZ J Obstet Gynaecol 1996;3: 361-3.

16 Kumar A, Mohan A, Gupta R, Singal VK, Garg P. Relapse of Wegener's granulomatosis in the first trimester of pregnancy: a case report. Br J Rheumatol 1998;37:331-3.

17 Dayoan ES, Dimen LL, Boylen C. Successful treatment of Wegener's granulomatosis during pregnancy. Chest 1998; 113:836-8.

18 Koldingsnes W. Pregnancy in Wegener's granulomatosis: a case report [abstract]. Scand J Rheumatol 1998;27(suppl 107):85.

19 Mackworth-Young CG, Morgan SH, Hughes GRV. Wegener's granulomatosis: onset during puerperium [letter]
Arthritis Rheum 1984;27:1314-15. 
20 Boumpas DT, Austin HA, Vaughan EM, Yarboro CH, Klippel JH, Balow JE. Risk of sustained amenorrhea in patients with systemic lupus erythematosus receiving intermitten pulses of cyclophosphamide. Ann Intern Med 1993;119: 366-9.

21 Buckley LM, Bullaboy CA, Leichtman L, Marquez M. Multiple congenital anomalies associated with weekly methotrexate treatment of the mother. Arthritis Rheum 1997;40:971-3.

22 Ramsey-Goldman R, Schilling E. Immunosuppressive drug use during pregnancy. Rheum Dis Clin North Am 1997; 23:149-67.

23 Czeizel A. A case-control analysis of the teratogenic effects of cotrimoxazole. Reprod Toxicol 1990;4:305-13.
24 Stegeman CA, Cohen Tervaert JW, de Jong PE, Kallenberg CG. Trimethoprim-sulfamethoxazole (co-trimoxazole) for the prevention of relapses of Wegener's granulomatosis. Dutch Co-Trimoxazole Wegener Group Study. N Engl J Med 1996;335:16-20.

25 Jayne DR, Lockwood CM. Intravenous immunoglobulin as sole therapy for systemic vasculitis. $\mathrm{Br} \mathrm{J}$ Rheumatol 1996;35:1150-3.

26 Cowchock S. Prevention of fetal death in the antiphospholipid antibody syndrome. Lupus 1996;5:467-72

27 Cowchock FS, Reece EA, Balaban D, Branch DW, Plouffe L. Repeated fetal losses associated with antiphospholipid antibodies: a collaborative randomized trial comparing prednisone with low-dose heparin treatment. Am J Obstet Gynecol 1992;166:1318-23. 